\title{
MUDHARABAH SEBAGAI PRODUK PEMBIAYAAN PERBANKAN SYARIAH PERSPEKTIF ABDULLAH SAEED
}

\author{
Moh. Nurul Qomar ${ }^{1}$ \\ ${ }^{1}$ Institut Agama Islam Negeri Kudus \\ $\triangle$ mnqomar84@gmail.com
}

\begin{abstract}
The aim of this research is to explore Abdullah Saeed's views on the practice of mudharabah contracts in Islamic banking. This research uses library research method and use a research to life history approach. Saeed's findings in the practice of mudharabah contracts in Islamic banking have constraints starting from capital, management, the validity period of contracts, guarantees, profit and loss principles that are different from the concept of mudharabah that develops in the science of figh. Abdullah Saeed concluded that the mudharabah contract in Islamic banks was different from the mudharabah contract that developed in the science of fiqh.
\end{abstract}

Keywords $\quad$ : Abdullah Saeed, mudharabah contracts, Islamic banking

\section{LATAR BELAKANG}

Berdirinya Perbankan syariah bertujuan untuk memperkenalkan suatu sistem untuk menggantikan mekanisme bunga dalam transaksi perbankan, yaitu transaksi berbasis profit and lost sharing atau lebih dikenal di Indonesia dengan sistem bagi hasil (Imama, 2014:222). Hal ini dibuktikan dengan undang-undang no. 7 tahun 1992 tentang perbankan, melalui pasal 6 huruf l. Pasal tersebut beserta penjelasannya tidak mempergunakan istilah bank islam atau bank syariah, melainkan hanya menyebutkan pembiayaan bagi nasabah berdasarkan prinsip bagi hasil sesuai dengan ketentuan dalam peraturan pemerintah.

Prinsip bagi hasil dalam akad mudharabah adalah kemitraan dan kebersamaan (sharing) antara investor (shohibul maal) dan pelaku usaha (mudharib), di mana di dalamnya terdapat unsur-unsur kepercayaan (amanah), kejujuran dan kesepakatan (Sa'diyah, 2013: 304). Akan tetapi pada penerapan prinsip bagi hasil tersebut tidaklah mudah karena jenis akad mudharabah terdapat banyak resiko dan membutuhkan biaya operasional yang lebih.

Dalam perkembangan transaksi pembiayaan oleh bank syariah di Indonesia lebih mengandalkan skema pembiayaan Murabahah (jual-beli) dibanding dengan skema pembiayaan Mudharabah (bagi-hasil). Hal tersebut dibuktikan hasil snapshot perbankan syariah di Indonesia yang dirilis oleh otoritas jasa keuangan (OJK) per Juni 2018 menunjukkan bahwa market share perbankan syariah mencapai 5,70\%, namun ketika berbicara transaksi akad sangat didominasi oleh akad murabahah berkisar $51,77 \%$. Musyarakah 36,86\%, sedangkan mudharabah pada level 5,27\% dan akad ijarah hanya pada $3,18 \%$. 


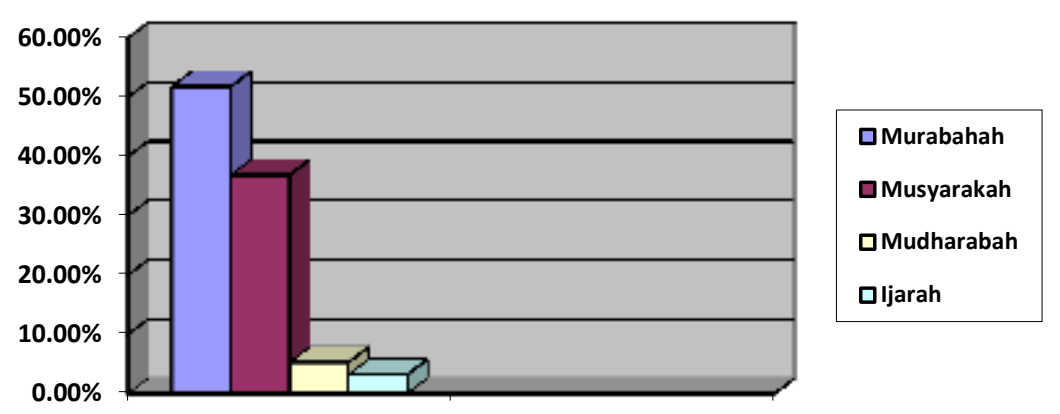

Prosentasi akad-akad bank syariah per Juni 2018

(Snapshot bank syariah dirilis 0JK)

Tingginya resiko pada akad mudharabah menjadikan alasan mengapa praktisi perbankan lebih memilih penyaluran pembiayaan kepada masyarakat menggunakan akad murabahah, akad ini dinilai lebih rendah resikonya dan pasti keuntungannya, padahal secara teoritis yang mempunyai dampak langsung kepada pertumbuhan ekonomi berupa tumbuhnya peluang usaha baru, kesempatan kerja baru, dan peningkatan pendapatan penduduk adalah pembiayaan dalam bentuk kerja sama, yaitu mudharabah maupun musyarakah (Perwataatmadja, 2002:13). Realita ini menunjukkan bahwa produk bagi hasil belum menjadi primadona di bank syariah. Pertanyaan yang muncul kemudian adalah mengapa pembiayaan bagi hasil khususnya mudharabah masih belum menjadi produk unggulan bagi masyarakat?

Menurut Abdullah Saeed melihat bahwa bank syariah dalam merealisasikan sistem bagi hasil, sebagaimana dijabarkan dalam teori, ternyata tidak dapat dimanfaatkan secara maksimal dalam sistem perbankan syariah yang menginginkan pihak bank mempunyai hak untuk turut menanggung beban resiko dari pembiayaan tersebut. Realitas ini mendorong bank syariah menempuh jalan dengan membatasi fleksibilitas konsep mudharabah tersebut dari sistem bagi hasil dan mencoba mentransformasikannya ke dalam mekanisme pembiayaan bebas resiko (Saeed, 2008: 91).

Penelitian sebelumnya tentang pandangan Abdullah Saeed terdapat pada beberapa jurnal ilmiah, seperti Riba dan Bunga Bank dalam Pandangan Abdullah Saeed (Hadi, 2014), Bunga Bank; antara paradigma tekstual dan kontektual (Hasyim, 2008), Riba dan Bunga Bank; (Studi Komparatif Pemikiran Abdullah Saeed dan Yusuf Qardhawi) (Wartoyo, 2012). Hukum Riba dan Bunga Bank dalam Perspektif EthicoLegal (Muhammad, 2012).

Di luar pemikiran Abdullah Saeed tentang riba dan bunga bank, masih belum banyak yang menyinggung persepsi Abdullah Saeed tentang praktek akad perbankan syariah, terutama akad mudharabah. Selanjutnya tulisan ini akan lebih detail mengupas pandangan Abdullah Saeed tentang praktek akad mudharabah dalam perbankan syariah. 


\section{TEORI DAN METODE}

\subsection{Mudharabah dalam lintasan sejarah}

Mudharabah disebut juga dengan qirodh yang berarti memutuskan. Dalam hal ini, si pemilik uang memutuskan untuk menyerahkan sebilang uangnya untuk diperdagangkan berupa barang-barang dan memutuskan sekalian dari keuntungannya bagi kedua orang yang berakad qirodh ini (Wiroso, 2005: 33). Kegiatan ekonomi berbasis mudharabah kerap dipraktekkan pada jaman jahiliyah, di mana karakter masyarakat pada waktu itu bekerja pada sektor perdagangan.

Muhammad sebelum menjadi Nabi berprofesi sebagai pedagang, juga melakukan akad mudharabah, termasuk kontrak mudharabah dengan khadijah, sebagai shohibul maal dan Muhammad sebagai mudharib melakukan perniagaan dari Mekkah ke Syam (Wiroso, 2005:34). Oleh karena itu, proses adobsi dan modifikasi terjadi pada masa rosulullah, di mana praktek-praktek mudharabah yang masih berbau riba dan ketidakadilan harus diselaraskan dengan aturan syariah, sehingga tidak mungkin para sahabat tidak terlibat dalam praktek akad mudharabah.

Pada abad pertengahan, perjanjian kerja sama mudharabah merupakan sarana ekonomi yang terpenting bagi masyarakat, yang menggunakan sumber daya keuangan dan manusia sekaligus untuk memenuhi tujuan perdagangan. Keadaan demikian berlangsung pada abad pertengahan baik di barat maupun di dunia muslim (Udovith, 2008:234). Meskipun mudharabah tidak secara langsung disebutkan oleh al-Qur'an atau Sunnah, mudharabah merupakan sebuah kebiasaan yang diakui dan dipraktikkan oleh umat Islam, dan bentuk dagang semacam ini tampaknya terus hidup sepanjang periode awal era Islam sebagai tulang punggung perdagangan.

Pengenalan istilah mudharabah bermula dari dunia Islam ke kota-kota pelabuhan italia pada akhir abad ke sepuluh dan awal abad ke sebelas, menyebabkan perdagangan eropa berkembang. Meskipun mudharabah menjadi bentuk yang telah mengakar pada masyarakat arab, Udovith berpendapat bahwa lembaga kerjasama syirkah maupun mudharabah bukanlah hasil penemuan atau buatan fiqh. Lebih lanjut Udovith memaparkan bahwa mudharabah telah diketahui dan digunakan di timur dekat, setidaknya sejak pemerintahan Babilonia. Mudharabah juga termuat dalam kitab Talmud. Sedangkan di kota Mekkah pada waktu itu sebagai sentral perdagangan, telah mengumpulkan pedagang dari berbagai Negara dengan bentuk perdagangan yang berbeda-beda. Selanjutnya mudharabah diterima sebagai bagian dalam hukum islam, karena tidak ada keterangan dari para ulama fiqh yang bertentangan (Udovith, 2008: 7). Berdasarkan hal tersebut, tidak diragunakan lagi bahwa mudharabah berasal dari kebiasaan turun temurun masyarakat arab sebelum islam.

Kemungkinan besar, mudharabah merupakan lembaga yang berasal dari semenanjung Arab, yang perkembangannya berlangsung di dalam lingkungan kafilah perniagaan orang-orang arab sebelum Islam. Pada saat penaklukan yang dilakukan oleh orang arab, mudharabah berkembang ke timur dekat. Afrika utara dan eropa selatan (Udovith, 2008).

Mudharabah yang menjadi contoh perjanjian perdagangan abad pertengahan sangat identik dengan lembaga resmi ekonomi yang terkenal di eropa (Ensiklopedia Tematis Dunia Islam, 2001:283) yaitu commenda. istilah commenda perkembangannya sampai masuk ke wilayah Indonesia, sebagaian literatur menyebutkan bahwa di berbagai Kesultanan Nusantara berlaku sistem kelembagaan 
kemitraan dagang (syarikah mufawadhah) dan sistem commenda atau kepemilikan modal (arab: qirad, mudharabah, mugharadhah).

Bukti lain dari pernyataan di atas adalah mun- culnya model bagi hasil yang telah lama dikenal oleh masyarakat Indonesia, yaitu teknik operasional bagi hasil tersebut umumnya berkonsentrasi pada masalah pertanian dan perkebuman. Sistem ini terdiri dari dua pihak, pemilik modal (ladang, bibit, pupuk dsb) sedangkan pihak lain menyediaakan tenaga terampil. Istilah bagi hasil tersebut, biasanya dikenal dengan paroan.

\subsection{Mudharabah dalam literatur fiqh}

Dalam literatur fiqh, terdapat dua istilah yang menunjukan pengertian mudharabah. Yang pertama istilah muqaradah dan yang kedua istilah Qiradh. Namun pengertian keduanya adalah sama saja. Istilah mudharabah adalah bahasa penduduk Irak dan kebanyakan digunakan oleh mazhab Hanafi, Hanbali dan Zaydi dan Qiradh adalah bahasa istilah yang digunakan penduduk Hijaz dan kebanyakan digunakan oleh mazhab Maliki dan Syafi'i. Sedangkan penduduk madinah menggunakan istilah muqaradah, di mana perkataan ini diambil dari kata qard yang berarti menyerahkan.

Di dalam al-Qur'an dan Hadits kata mudharabah tidak disebutkan secara jelas. Al-Qur'an hanya mengungkapkan akar kata dari mudharabah yang terdiri dari huruf d-r-b sebanyak lima puluh delapan kali tetapi penggunaannya tidak secara langsung menunjuk istilah mudharabah (Udovitch, 2008). Diantara jumlah itu, terdapat kata yang dijadikan sebagian besar ulama' fiqh sebagai landasan hukum dari mudharabah yaitu dharaba fi al-ardi (QS. 2:275) yang artinya berjalan dimuka bumi. mereka menganggap bahwa yang dimaksud berjalan di muka bumi ini adalah bepergian ke suatu wilayah untuk suatu perdagangan.

Istilah mudharabah diambil dari kata dharib, Dinamakan demikian karena dharib berhak untuk menerima bagian keuntungan atas dukungan dan kerjanya. Secara rinci mudharabah adalah suatu kontrak kemitraan (partnership) yang berlandaskan pada prinsip pembagian hasil dengan cara seseorang memberikan modalnya kepada yang lain untuk melakukan bisnis dan kedua belah pihak membagi keuntungan atau memikul beban kerugian berdasarkan isi perjanjian bersama (Rahman, 1995: 380).

Menurut Hanfiyah, mudharabah adalah suatu perjanjian untuk berkongsi di dalam keuntungan dengan modal dari salah satu pihak dan kerja (usaha) dari pihak lain. Menurut Madzhab Maliki yaitu penyerahan uang dimuka oleh pemilik modal dalam jumlah uang yang ditentukan kepada seorang yang akan menjalankan usaha dengan uang itu dengan imbalan sebagian dari keuntungannya. Menurut madzaab syafi'i mendefinisikan dengan pemilik modal menyerahkan sejumlah uang kepada pengusaha untuk dijalankan dalam suatu usaha dagang dengan keuntungan menjadi milik bersama antara keduanya. Sedangkan menurut Madzhab Hanbali yakni penyerahan suatu barang atau sejenisnya dalam jumlah yang jelas dan tertentu kepada orang yang mengusahakannya dengan mendapatkan bagian tertentu dari keuntungannya (dalam Muhammad, 2004: 82-83). Selanjutnya Muhammad melakukan analisis sebagai berikut salah satu hal yang mungkin terlupakanan dari definisi-definisi yang dikemukakan oleh para ahli fiqh klasik adalah bahwa kegiatan kerjasama mudharabah merupakan jenis usaha yang tidak secara otomatis mendatangkan untung/hasil. Oleh karena itu penjelasan mengenai untung dan rugi perlu di tambahi sebagai bagian yang integral dari sebuah definisi yang baik. 
Hal ini karena dalam mudharabah tidak saja mempertimbangkan aspek keuntungan dalam usahanya tersebut namun juga mempunyai konsekuensi untuk mengalami kerugian. Sehingga kerugian modal ditimpakan kepada penyedia modal sedangkan kerugian tenaga, keterampilan dan kesempatan mendapat laba ditanggung oleh pengusaha / pengelola.

Dalam hal ini, pemilik modal akan menyerahkan hak atas pengelolaan modal tersebut kepada pengelola. Keuntungan dibagi menurut kesepakatan yang dituangkan dalam kontrak. Apabila rugi maka akan ditanggung pemilik modal selama kerugian itu bukan akibat dari kelalaian si pengelola. Apabila kerugian diakibatkan kelalaian pengelola, maka si pengelolalah yang bertanggung jawab.

Mudharabah di bagi menjadi 2; Pertama, mudharabah muthlaqah merupakan kerjasama antara pihak pertama dan pihak lain yang cakupannya lebih luas. Maksudnya tidak dibatasi oleh waktu, spesifikasi usaha dan daerah bisnis. Kedua, mudharabah muqayyadah merupakan kebalikan dari mudharabah muthlaqah di mana pihak lain dibatasi oleh waktu spesifikasi usaha dan daerah bisnis.

\subsection{Biografi singkat Abdullah Saeed}

Biografi tidak ditemukan oleh peneliti dari data primer, sehingga peneliti mengambil dari data sekunder yaitu dari jurnal ilmiah, sebagai berikut (Hadi, 2014);

Abdullah Saeed adalah seorang profesor Studi Arab dan Islam di Universitas Melbourne, Australia. Sekarang ini dia menjabat sebagai Direktur Pusat Studi Islam Kontemporer di universitas yang sama. Saeed lahir di Maldives, keturunan suku bangsa Arab Oman yang bermukim di pulau Maldives.

Pada tahun 1977, dia hijrah ke Arab Saudi untuk menuntut ilmu di sana. Di Arab Saudi, dia belajar bahasa Arab dan memasuki beberapa lembaga pendidikan formal di antaranya Institut Bahasa Arab Dasar (1977-1979) dan Institut Bahasa Arab Menengah (1979-1982) serta Universitas Islam Saudi Arabia di Madinah (19821986). Tahun berikutnya, Saeed meninggalkan Arab Saudi untuk belajar di Australia. Di negara kanguru ini, Saeed memperoleh beberapa gelar akademik, bahkan sampai sekarang tetap mengajar pada salah satu universitas terkenal dan terkemuka di dunia. Saeed dikenal sebagai dosen yang ulet.

Di Australia, Abdullah Saeed mengajar Studi Arab dan Islam pada program strata satu dan program pasca sarjana (program S2 dan S3). Di antara mata kuliah yang diajarkan adalah Ulumul al-Qur'an, Intelektualisme Muslim dan Modernisasi, Pemerintahan dan Peradaban Islam, Keuangan dan Perbankan Islam, Hermeneutika al-Qur'an, Metodologi Hadits, Usul al-Fiqh, Kebebasan Beragama di Asia, Islam dan Hak Asasi Manusia, dan Islam dan Muslim di Australia.

Pada tahun 1993, dia diangkat sebagai asisten dosen pada Jurusan Bahasabahasa Asia dan Antropologi di Universitas Melbourne. Kemudian pada tahun 1996 menjadi dosen senior pada perguruan tinggi yang sama, dan menjadi anggota asosiasi profesor pada tahun 2000. Pada tahun 2003, Saeed berhasil meraih gelar professor dalam bidang Studi Arab dan Islam. Saeed dinilai sebagai seorang yang berwawasan luas, profesional serta konsisten terhadap keilmuan. Di tengah kesibukannya mengajar dan menulis, Saeed banyak diikutsertakan dalam pertemuan dan seminarseminar internasional. Saeed juga terlibat dalam berbagai kelompok dialog antar kepercayaan, antara Kristen dan Islam, dan antara Yahudi dan Islam. Karena kemahiranya dalam beberapa bahasa: Inggris, Arab, Maldivia, Urdu, Indonesia dan Jerman, membuatnya sering mengunjungi beberapa negara: Amerika Utara, Eropa, Timur Tengah, Asia Selatan dan Asia Tenggara. Bahkan dia memiliki banyak relasi 
pakar dan riset di seluruh dunia. Karena kemahiran dan sepak terjang dan keseriusannya di dunia keilmuan, nama Saeed menjadi popular dan diperhitungkan di dunia internasional. Berikut ini akan diuraikan secara lebih terperinci biografi intelektual Abdullah Saeed Abdullah Saeed telah menyandang gelar akademik yang diperolehnya dari Arab Saudi dan Australia.

\subsection{Metode Penelitian}

Untuk menjawab permasalahan yang dikemukakan pada latar belakang, digunakan metode penelitian, yaitu penelitian kepustakaan (library research). Langkah pertama dalam penelitian ini adalah inventarisasi sumber data (Anton, 1990:73), yaitu pengumpulan bahan pustaka yang relevan dengan topik penelitian, sesuai dengan tujuan penelitian. Selain itu peneliti menggunakan pendekatan penelitian studi tokoh (life history) (Furchan dan Maimun, 2005: 23), karena berupaya meneliti gagasan-gagasan, sudut pandang dari seorang tokoh Abdullah Saeed.

\section{PEMBAHASAN}

Mudharabah didefinisikan sebagai akad kerja sama antara bank selaku pemilik dana (Shohib al-Maal) dengan nasabah selaku mudharib yang mempunyai keahlian atau ketrampilan untuk mengelola suatu usaha yang produktif dan halal. Hasil keuntungan dari penggunaan dana tersebut dibagi bersama berdasarkan nisbah yang disepakati (Muhamad, 2016).

Melihat definisi tersebut di atas, pembiayaan akad mudharabah terkesan sederhana dan sangat mudah untuk dipraktekkan di bank syariah. Untuk memahami akad mudharabah sebagai perwujudan dari profit and Loss Sharing (PLS), maka bank syariah wajib memberikan sumber pembiayaan yang luas kepada peminjam berdasarkan atas bagi resiko (baik menyangkut keuntungan maupun kerugian), yang berbeda dengan pembiayaan system bunga pada dunia perbankan konvensional yang semua resikonya ditanggung oleh pihak peminjam (Saeed, 2008).

Gambaran praktek pembiayaan akad mudharabah dimulai dari pihak nasabah sebagai calon mudharib mengajukan permohonan pembiayaan akad mudharabah pada bank syariah dengan melengkapi persyaratan yang diwajibkan oleh pihak bank syariah. Pihak bank syariah melakukan observasi lapangan tentang kebenaran keterangan yang diberikan oleh nasabah. Selanjutnya bank syariah melakukan musyawarah internal untuk memutuskan disetujui atau ditolak permohonan nasabah. Tentunya pihak bank akan menyetujui melakukan pembiayaan usaha tersebut jika tingkat keuntungan yang diharapkan cukup menjanjikan dan tingkat pengembalian modal sangat tinggi.

Merujuk pada praktek perbankan syariah yang ada, praktek pembiayaan mudharabah tidak berjalan sesuai dengan definisi dan teori, terdapat beberapa masalah yang berkaitan dengan penggunaan profit and Loss Sharing (PLS) pada akad mudharabah, antara lain; a. Standar moral b. Ketidakefektifan model pembiayaan profit and Loss Sharing (PLS) c. Berkaitan dengan para pengusaha d. Dari segi biaya e. Segi teknis f. Kurang menariknya system profit and Loss Sharing (PLS) dalam aktivitas bisnis g. Permasalahan efisiensi (Saeed, 2008), sehingga bank syariah menilai pembiayaan akad mudharabah terlalu beresiko dan membutuhkan biaya operasional yang tinggi, untuk itu bank syariah sangat hati-hati dan terkesan menghindari pembiayaan akad mudharabah. 
Lebih lanjut Saeed menjelaskan secara detail komponen-komponen pembiayaan akad mudharabah yang dipraktekkan di perbankan syariah, antara lain;

a. Modal

Tujuan dari akad mudharabah adalah ketersedian modal bagi pelaku usaha dalam menjalankan kegiatan usahanya. Sinergi antara pemilik modal dan skill pelaku usaha akan menghasilkan profit yang akan dibagi sesuai kesepakatan nisbah di awal.

Kritik Saeed terhadap praktek akad mudharabah di bank-bank syariah adalah tidak ada kebebasan pelaku usaha dalam menjalakan usahanya. Pelaku usaha hanya dituntut menjalankan usahanya sesuai dengan isi perjanjian akad mudharabah antara pelaku usaha dengan bank syariah. Bank syariah juga melakukan pengawasan dan kontrol terhadap pelaksanaan usaha yang didanai, salah satu bentuknya adalah tidak memberikan dana mudharabah secara langsung kepada pelaku usaha untuk memastikan tidak ada penyelewengan dana mudharabah. Praktek akad mudharabah tersebut di atas sangat berbeda dengan akad mudharabah yang berkembang dalam ilmu fiqh, yaitu akad yang memberikan kebebasan kepada pelaku usaha dalam menjalankan usahanya (Saeed, 2008).

Pengawasan dan kontrol merupakaan prinsip kehatihatian pihak bank syariah dalam menjaga amanah (posisi mudharib) dari pihak nasabah (shohibul maal). Artinya kesiapan pihak bank syariah dalam menjalankan prinsip bukan hanya bagi hasil tetapi juga bagi rugi sesuai dengan teori dasar akad mudharabah perlu disangsikan, dikarenakan pihak bank juga dituntut untuk memberikan bagi hasil kepada nasabah sebagai shohibul maal. Bisa jadi pihak bank syariah tidak siap menanggung kerugian yang dilakukan pelaku usaha, maka pihak bank syariah berusaha membuat alasan bahwa usaha tersebut rugi karena kesalahan pelaku usaha, sehingga pelaku usaha harus ikut menanggung kerugian akan modal mudharabah. Hal ini merupakan kelemahan akad mudharabah dipraktekkan pada institusi bank yang berperan ganda (mudharib dan shohibul maal).

b. Manajemen

Menurut fatwa DSN No.07/ DSN-MUI/IV/200 tentang akad mudharabah disebutkan bahwa mudharib boleh melakukan berbagai macam usaha yang telah disepakati bersama sesuai dengan syariah, dan lembaga keuangan syariah tidak ikut serta dalam manajemen perusahaan atau proyek tetapi mempunyai hak untuk melakukan pembinaan dan pengawasan.

Dalam hal pembinaan dan pengawasan yang dilakukan oleh pihak bank syariah, pelaku usaha sering merasa keberatan dan kesulitan dalam memenuhinya, seperti pelaporan keuangan usaha tiap bulannya. Konsekuensi lain dari fatwa DSN tersebut adalah pelaku usaha bertanggung jawab untuk menanggung segala kerugian yang disebabkan oleh kesalahannya sendiri yang melanggar ketentuan dari perjanjian akad mudharabah.

Saeed menjelaskan manajemen praktek akad mudharabah yang berkembang dalam ilmu fiqih, pihak mudharib diberikan kewenangan yang luas terhadap modal seperti diperbolehkan membelanjakan modal tersebut setiap saat dan setiap waktu (Saeed, 2008).

Kesimpulan praktek mudharabah di perbankan syariah adalah pelaku usaha harus patuh terhadap syarat dan ketentuan yang tercantum pada perjanjian akad mudharabah.

c. Masa berlakunya kontrak

Kritik Saeed terhadap praktek mudharabah dalam perbankan syariah adalah sering kali akad ini digunakan untuk kegiatan usaha yang bersifat jangka pendek 
(short term commercial) (Saeed, 2008). Tujuan pihak bank syariah memberlakukan hal tersebut agar pihak bank syariah mudah menghitung keuntungan dari bagi hasil dari masa kontrak akad mudharabah yang telah ditentukan yang bersifat jangka pendek.

Namun di sisi lain apabila pelaku usaha tidak secara maksimal menggunakan dana tersebut selam masa yang ditentukan, maka dia harus memberikan kompensasi dan mengembalikan dana mudharabah kepada bank atas segala kerugian yang terjadi dan kontrak otomatis dihentikan oleh pihak bank (Saeed, 2008).

Secara keseluruan aturan masa berlakunya kontrak tertuang pada isi perjanjian akad mudharabah. Perjanjian yang terstandart yang dibuat oleh pihak bank akan sangat tidak cocok jika digunakan dalam perjanjian kerja sama, seperti akad mudharabah yang menggunakan prinsip syariah. Karena dalam prinsip syariah kesepakatan tidak boleh ditetapkan sepihak, sehingga berapa nisbah bagi hasil nasabah pembiayaan haruslah jelas disepakati. Besarnya rasio bagi hasil bisa lebih besar untuk nasabah pembiayaan atau sebaliknya dan tidak menutup kemungkinan nisbah bagi hasil tersebut sama bagi kedua belah pihak ( $N a$ 'im, 2017). Dalam prakteknya pembagian nisbah antara bank dan nasabah pada produk jasa bank khususnya pembiayaan mudharabah ini, dimana bank membiayai $100 \%$, sehingga nisbah yang diterima bank relatif lebih besar dari nasabah. Pembagian nisbah antara bank dan nasabah memang tidak terjadi perdebatan dalam arti terjadi kesepakatan antara bank dan nasabah (Fadhila, 2015).

Selain itu ketika masa berlakunya perjanjian akad mudharabah ditentukan oleh pihak bank syariah dan tanpa mempertimbangkan kondisi pelaku usaha, maka hal tersebut sangat memberatkan nasabah.

d. Jaminan

Jaminan pada akad mudharabah merupakan seuatu hal pembeda antara konsep mudharabah yang dibahas dalam kitab fiqh klasik dan praktek akad mudharabah di bank syariah. Konsep mudharabah yang berkembang dalam ilmu fiqh bahwa mudharib tidak diperkenankan untuk diwajibkan memberikan jaminan (collateral) kepada shohibul maal. Hal ini tetap dilakukan oleh pihak bank syariah bertujuan agar mudharib secara konsisten melaksanakan isi perjanjian akad mudharabah yang telah ditandatangani. Jaminan tersebut tidak dimaksudkan untuk memastikan kembalinya modal yang telah diberikan kepada mudharib.

Akan tetapi Saeed dalam melakukan penelitian menumukan bahwa salah satu isi perjanjian di faisal Islamic bank of mesir (FIBE) menyebutkan bahwa "jika terbukti mudharib tidak memanfaatkan dana atau tidak menjaga barang dagangan sebagaimana mestinya berdasarkan ketentuan persyaratan dari investor, di mana mudharib mengalami kerugian, maka jaminan yang diberikan dijadikan sebagai ganti atas kerugian yang dialaminya.

Mudharib diwajibkan untuk membuat laporan perkembangan tiap jangka waktu tertentu sesuai permintaan pihak bank syariah. Selain tiu pihak bank syariah menuntuk laporan keuangan dan laporan laba rugi untuk mengetahui perkembangan usaha secara financial. Lebi lanjut Saeed menjelaskan beban mudharib ketika mengalami kegagalan dalam mencapai target yang ditentukan pihak bank syariah, maka pihak bank diperbolehkan mengambil alaih manajemen usahanya (Saeed, 2008).

Dari gambaran tersebut peneliti menyimpulkan bahwa akad mudharabah yang notabennya akad yang memerlukan musyawarah, maka akan terjadi ketidakadilan 
ketika posisi mudharabah dibatasi sebagai pelaksana isi perjanjian akad mudharabah. Permasalahan ini berdampak pada kuantitas dan kualitas hasil dari akad mudharabah dikarenakan pihak pelaku usaha merasa terbebani terlebih dahulu sebelum melakukan kegiatan usaha. Efek dari model akad mudharabah seperti ini adalah nasabah tidak akan melirik atau tidak jadi melakukan pembiayaan dengan bank syariah.

\section{e. Prinsip bagi hasil (profit and Loss Sharing)}

Praktek mudharabah secara tekni dijelaskan sebagai akad kerja sama antara dua pihak di mana pihak pertama (shohubul maal) menyediakan seluruh modal sedangkan pihak lainnya menjadi pengelola. Keuntungan usaha secara mudharabah dibagi menurut kesepakatan yang dituangkan dalam kontrak, sedangkan apabila rugi ditanggung oleh pemilik modal selama kerugian itu bukan akibat kelalaian si pengelola (Muhamad, 2016).

Saeed menilai praktek akad mudharabah di bank syariah menghilangkan karakter ketidaktentuan hasil usaha dengan menggunakan akad ini pada kegiatan usaha yang bersifat jangka pendek (short term commercial). Dengan begitu hasil usaha mampu diprediksi oleh pihak bank syariah. Dengan kata lain bank syariah membuat praktek akad mudharabah sangat minim resiko atau bebas resiko.

Secara teoritis system bagi hasil, bank syariah bertanggung jawab atas kerugian atas modal usaha, tetapi tidak demikian pihak bank syariah tidak begitu saja percaya kerugian yang dialami oleh pelaku usaha. Selanjutnya Saeed menyimpulkan bahwa akad mudharabah yang dipraktekkan oleh bank syariah secara signifikan berbeda dari akad mudharabah sebagaimana umumnya yang dikembangkan dalam hukum islam (Saeed, 2008).

\section{PENUTUP}

Temuan Saeed dalam praktek akad mudharabah di perbankan syariah terdapat kendala dimulai dari modal, manajemen, masa berlakunya kontrak, jaminan, prinsip bagi hasil (profit and Loss Sharing) yang berbeda dengan konsep mudharabah yang berkembang dalam ilmu fiqh. Abdullah Saeed berkesimpulan bahwa akad mudharabah di bank syariah berbeda dengan akad mudharabah yang berkembang dalam ilmu fiqh. 


\section{DAFTAR PUSTAKA}

Afzalurrahman. (2003). Doktrin Ekonomi Islam. Yogyakarta: PT dana Abadi Wakaf.

Anton, B., dan Ahmad, C.Z. (1990). Metode Penelitian Filsafat. Yogyakarta: Kanisius.

Ekonomi Masa Kesultanan. 2002. Ensiklopedia Tematis Dunia Islam: Khilafah dalam bagian "Dunia Islam Bagian Timur". Jakarta: PT Ichtiar Baru Vab Hoeve.

Udovitch, Abraham, l. (2008). Kerja Sama Syari'ah dan Bagi Untung-Rugi dalam Sejarah Islam Abad Pertengahan. Kediri: Qubah.

Wiroso. (2005). Penghimpunan Dana dan Distribusi Hasil Usaha Bank Syari'ah. Jakarta: Grasindo.

Saeed, Abdullah. (2008). Bank Islam dan Bunga; Studi Kritis dan Interprestasi Kontemporer tentang Riba dan Bunga. Yogyakarta: Pustaka Pelajar.

Muhamad. (2016). Manajemen Keuangan Syari'ah; Analisis Fiqh dan Keuangan. Yogyakarta: Upp STIM YPKN.

Imama, Lely Shofa. 2014. Konsep dan Implementasi Murabahah pada Produk Pembiayaan Bank Syariah, Jurnal Iqtishadia Vol. 1, No. 2, Desember 2014, 222-247

Hadi, A. Chairul. 2011. Problematika Pembiayaan Mudharabah di Perbankan Syariah Indonesia, Jurnal al-Iqtishod Vol. 3, No.2, Juli 2011, 194-209

Sa'diyah, Mahmudatus dan Meuthiya Athiya Arifin. 2013. Mudharabah dalam Fiqh dan Perbankan Syari'ah, Jurnal Equilibrium Vol. 1 No.2, Desember 2013, 302323 